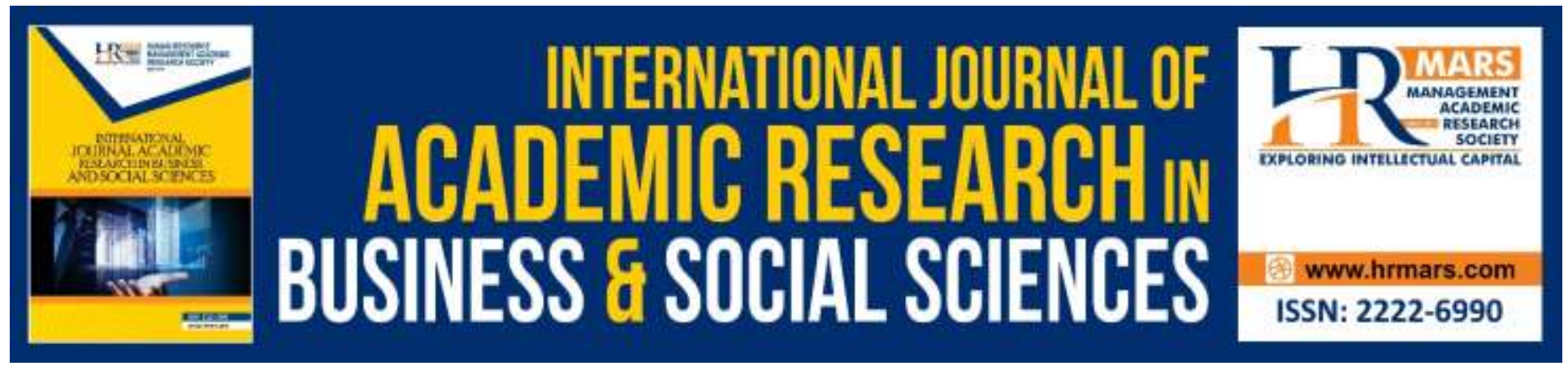

\title{
The Concept of Mut'ah Granting After Divorce in Islam
}

Siti Norbalqis Binti Ahmad Zizan, Wan Khairul Aiman Wan Mokhtar, Asma Afifah Rashid Eusoff Amiruddin, Ahmad Safwan Jamaludin

To Link this Article: http://dx.doi.org/10.6007/IJARBSS/v9-i11/6580

DOI: 10.6007/IJARBSS/v9-i11/6580

Received: 11 October 2019, Revised: 28 October 2019, Accepted: 02 November 2019

Published Online: 27 November 2019

In-Text Citation: (Zizan, Mokhtar, Amiruddin \& Jamaludin, 2019)

To Cite this Article: Zizan, S. N. B. A., Mokhtar, W. K. A. W., Amiruddin, A. A. R. E., Jamaludin, A. S. (2019). Thr Concept of Mut'ah Granting After Divorce in Islam. International Journal of Academic Research in Business and Social Sciences, 9(11), 597-606.

Copyright: (C) 2019 The Author(s)

Published by Human Resource Management Academic Research Society (www.hrmars.com)

This article is published under the Creative Commons Attribution (CC BY 4.0) license. Anyone may reproduce, distribute, translate and create derivative works of this article (for both commercial and non-commercial purposes), subject to full attribution to the original publication and authors. The full terms of this license may be seen at: http://creativecommons.org/licences/by/4.0/legalcode

Vol. 9, No. 11, 2019, Pg. 597 - 606

http://hrmars.com/index.php/pages/detail/IJARBSS

JOURNAL HOMEPAGE

Full Terms \& Conditions of access and use can be found at http://hrmars.com/index.php/pages/detail/publication-ethics 


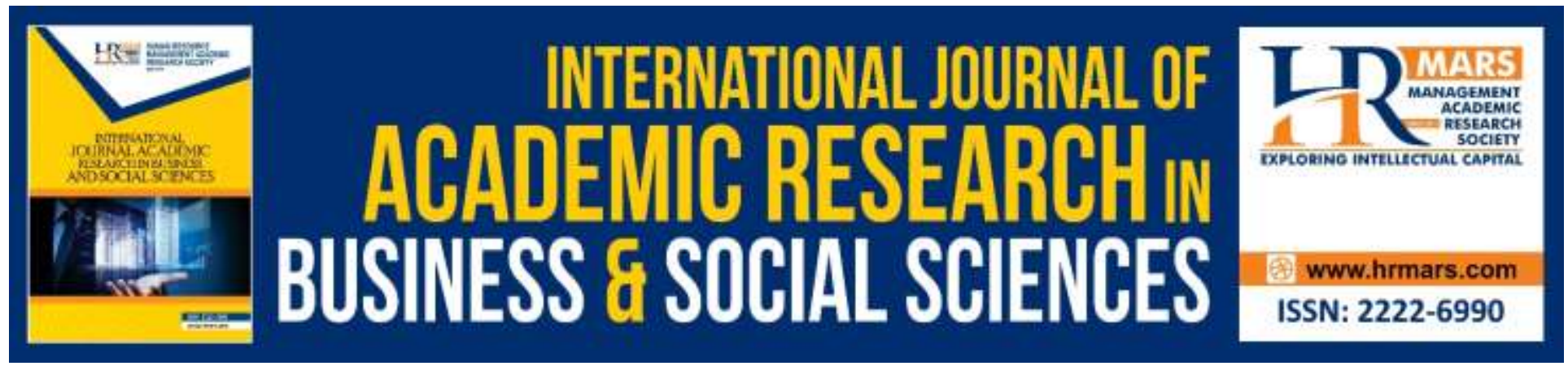

\title{
Thr Concept of Mut'ah Granting After Divorce in Islam
}

\author{
Siti Norbalqis Binti Ahmad Zizan, Wan Khairul Aiman Wan \\ Mokhtar, Asma Afifah Rashid \\ Eusoff Amiruddin, Ahmad Safwan Jamaludin \\ Universiti Sultan Zainal Abidin (UniSZA), Gong Badak Campus, 21300, Kuala Nerus, Terengganu, \\ Malaysia
}

\begin{abstract}
Mut'ah is the gift of a former husband to his divorced wife in the form of money, goods, and so forth. Undeniably, mut'ah requests often become issues and problems among the people. Furthermore, the understanding and awareness of the mut'ah after the divorce is very poor and at the critical stage of understanding. In the meantime, the objective of this study is to help the people in deepening religious knowledge, especially regarding mut'ah giving to ex-wife. Hence, through this study it is also possible to elaborate the meaning of mut'ah after the divorce in Islam in depth. In line with the objectives to be achieved, the researcher has put forward some questions that are the subject of research to be carried out. Among the questions is what is the true meaning or concepts of giving mut'ah after divorce according to Islam? In addition, what is the mut'ah rate that should be accepted by ex-wife after divorce according to Islam? Hence, what a woman right to mut'ah. The findings of this study is used the type of qualitative methods. This enables researchers to obtain data or information on the granting of mut'ah after divorce in Islam more profoundly. Research information was obtained through library and data obtained through document analysis. The finding shows that the researcher can explain in more details the concept of mut'ah after divorce, according to Islam. Furthermore, it is possible to identify mut'ah rates that should be accepted by ex-wife after divorce according to Islam and women's rights in mut'ah acceptance.
\end{abstract}

Keywords: Mut'ah, Objectives, Concepts, Qualitative Methods, Research Information

\section{Introduction}

Islam is a religion that carries the maslahah of human life, including the life of a woman after divorce with her husband. In order to ensure that the persecution is not particularly against women and to ensure justice is achieved, Islam has outlined certain regulations that must be 
followed. Some of the things that are meant are matters arising from the dissolving of marriage. Among these things are dowry (if in debt), iddah wife's maintenance, childbirth, homelessness, hadhanah, matrimonial property and mut'ah.

Lately, various questions about mut'ah's demand have often been attentive. The public are interested in knowing more about this because they are less aware of it. They also ask many questions about mut'ah such as the true meaning of mut'ah, the rate of mut'ah giving to the exwife and what the rights of women to mut'ah. This situation may be due to certain changes such as demands for mut'ah rates requested, poor educated, open-minded, and others.

The study was conducted to explain the concept of giving mut'ah after divorce according to Islam. In addition, this study was conducted to identify the value of mut'ah rates that should be accepted by ex-wife according to Islam. Furthermore, this study was conducted to explain the woman right in mut'ah.

In general, the rationale for this study is to produce a Muslim personality that is familiar and practicing Islamic principles, especially on the concept of giving mut'ah after divorce.

\section{Research Methodology}

The findings of this study is used the type of qualitative methods, which is use library method and the data obtained by document analysis. This enables researchers to obtain data or information on the granting of mut'ah after divorce in Islam more profoundly (Mokhtar, 2017).

\section{Findings and Research Discussion}

For the purpose of discussing the understanding of mut'ah granting after divorce, it has been divided into three main issues. First, the concept of mut'ah in Islam. Second, the rates of mut'ah that the former husband need to give to their ex-wife after divorce. Lastly, the woman right to mut'ah.

\section{The Concept of Mut'ah}

\section{The Definition of Mut'ah}

According to Ibn-Manzur (1990), mut'ah is a derivative word (masdar) of the word mata'a, yamta'u and mut'ah that means to bring something, fun, pleasure or enjoyment.

Some other scholars of Islam also give some humper interpretations as they have already stated. For example, Al-Bustani, defines mut'ah as something that can be beneficial to him whether there are many or few except gold and silver. While Al-Fayyumi and Al-Zuhayli define mut'ah as every one can enjoy its benefits such as food, clothing, home appliances and so on.

In Mu'jam Al-Wasit (1972), mut'ah words in the language are defined as gifts given after the happening of a divorce that can bring joy. Therefore, the gift must be of value and can be enjoyed by the recipient as food, property, clothing, vehicle, maid, and others.

Based on some of the definitions already stated, the researcher chooses the definition of mut'ah stated in Mu'jam Al-Wasit as the definitions of mut'ah this study which is a gift given after the happening of a divorce that can bring joy. 


\section{The Evidence of Mut'ah Granting After Divorce}

In the Qur'an there are many verses that prove mut'ah's instruction in divorce for some reason. Among the verses of the Qur'an that touch on the question are:

The Word of God S.W.T.

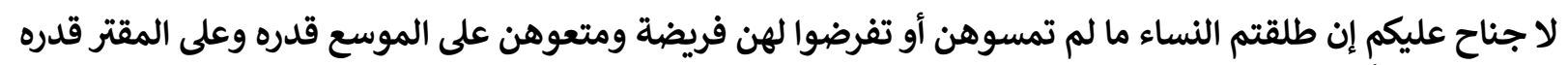

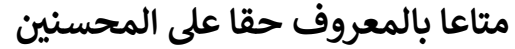

Which means: "There is nothing (dowry) upon you, if you divorce your wives before you touched them and before you determine their dowry. And give them mut'ah (gifts) to them. The person who is capable of according to his ability also, the gift according to the proper. Thus it defines the provisions for those who have taqwa".

Surah al-Baqarah (2): 236

In the above paragraphs explain that Allah S.W.T does not forbid a person to divorce his untrained and unborn wives. However, the husband is obliged to pay mut'ah to the divorced wife because in the verse above Allah states 'wa mattiuhunna' which means giving something that can please them (divorced wives) from your property according to your ability.

In the above verse also, Allah S.W.T uses the word touching for the purpose of mixing or intercourse aladal a kinayah which is very smooth and polite as is often expressed in other Quranic verses. According to Abu Muslim, in Tafsir al-Kabir, the benefits used by Allah S.W.T is an education to all mankind so that in his daily conversation should often choose beautiful words and words (Razi, 1974).

Hence, Hadith is the source of the second Islamic law of law after the Quran. If there is a problem and the solution is not found in the Qur'an, then it should be referred to Hadith. Therefore, the proposition of mut'ah mutation is also found in some of the Prophets of the Prophet S.A.W. Narrated by Anas bin Malik RA, the Prophet said:

$$
\begin{aligned}
& \text { عن أنس بن مالك, أن النبي صلى الله عليه وسلم رأى على عبد الرحمن بن عوف أثر صفرة, فقال: „إما هذا? «ه قال: يا }
\end{aligned}
$$

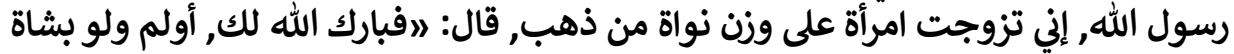

Translation: "Anas b. Malik reported that Allah's Apostle (may peace be upon him) saw the trace of yellowness on 'Abd al-Rahman b. 'Auf and said: What is this? Thereupon he said: Allah's Messenger, I have married a woman for a date-stone's weight of gold. He said: God bless you! Hold a wedding feast, even if only with a sheep."

(Narrated by Muslim in The Book of Marriage, number 3556)

\section{The Law of Mut'ah}

Scholars differ in opinion regarding the law of mut'ah giving to the wife after divorce.

a) According to Jumhur Fuqaha '

Mut'ah law according to jumhur fuqaha' is obligatory. Husband obliged to give mut'ah to the divorced wife before dissolubuhi and the dowry not mentioned in the contract.

b) The Hanafi School

According to the Hanafi sect, mut'ah position can be compulsory and can be the circumcision of the law depending on the circumstances of wives during divorce. The existence of this law is 
different because the divorced spouses are not of equal status to each other. In this case, the scholars of the Hanafi sect view the following:

i. Required

Husband must pay and divide mut'ah to wives who have been divorced if there is no relationship of the kind of marriage during the marriage and not determined a dowry in the contract or the dowry has been mentioned, but the dowry is damaged or 'fasid' such as making liquor, pig and others as dowries is not allowed by Hukum Syarak.

ii. Circumcision

According to scholars of 'Hanafi school, mut'ah mut'ah is circumcised only when a divorced wife has been dissolved and her marriage has been determined. Being circumcised mut'ah because divorce should be done properly and the best of divorce is accompanied by mut'ah. Likewise, the law applies to wives who are divorced and have been disbanded but have not been assigned marriages. The reason is that the wives have had the right over the mashwah mithil (mahar mithl) ie the unmarried women who are unspecified at the time of the contract and are paid to the bride according to the dowry of the bride's sisters, then they are no longer obliged to be given mut'ah (al-Hamid, 1966; Anal, Ahmad, Razalli, \& Min, 2018).

c) Maliki School

Imam Maliki and all Maliki fuqaha' states that mut'ah is merely a payment or consolation or courtesy as a repetition of sympathy and sympathy from the husband to the divorced wives. Mut'ah law is circumcision. Hence, the husband is not obliged, but is only encouraged to pay or give mut'ah to the wives. (Ibn-Rusyd, 1970)

d) Mazhab Hanbali

Imam Ahmad Hanbali states that mut'ah is a husband's obligation to divorced wives regardless of whether he is an independent, slave, or infamous 'zimmi'. This law is based on the command (sighah amr) on the word 'matti'uhunna' in Surah al-Baqarah, verse 241.

However, mut'ah law is obligatory in the event of a divorce before the occurrence of intercourse and the marriage is not yet determined. If the dowry is called after the contract and there is a divorce before intercourse, the wife is entitled to mut'ah only. (Ibn-Qudamah, 1981)

In conclusion, based on the above opinions it is clear that the granting of mut'ah to the wife is a demanded by Syariah laws on the husband after the divorce.

\section{The Rate of Mut'ah Giving in Islam}

Mut'ah rates are not specified specifically whether in Quran or al-Hadith. The determination of the rate and the principle that determines the amount of mut'ah is based on the word of Allah S.W.T, which means:
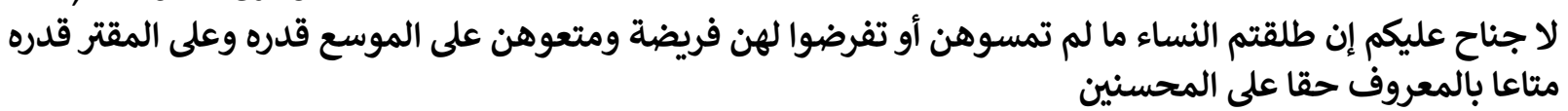

"There is nothing (dowry) upon you, if you divorce your wives before you mingle with them and before you determine their dowry. And give a mut'ah to them. People who are able to follow their 
abilities and the poor according to their ability (ie) the gift accordingly. That is a provision for those who do virtue."

(Surah al-Baqarah (2): 236)

According to Imam Malik bin Anas, the above verse is a powerful evidence that Allah S.W.T does not set mut'ah rates with certain values or rates. It is only stated in general, according to the ability of a husband whether poor or rich. If the husband is rich, his mut'ah rate should be appropriate to his wealth. On the other hand, for the poor husband, his mut'ah rate is only to the extent of his ability. (Ibn-Qudamah, 1981). This is the fact that the mut'ah rate that should be given is not set by Hukum Syarak, but is left to the current situation of a place. Therefore, in this case it requires ijtihad (Muhammad, 1967; Njimu, Theuri, Kiragu, 2018).

The ulama' figh disagreed in assessing the minimum and maximum rates of mut'ah. Imam Malik argues that mut'ah does not limit its rate to certain limits. At least mut'ah is anything that has value and no determination at its maximum. Mut'ah rates should be based on the husband's position in terms of the poor riches without having to refer to the position of the wife. (IbnJuzayy, 1968)

In this regard, Imam al-Syafi'i also thinks so. He states that for a person who can be circumcised mut' ah is a slave (khadam), for the middle class, its value is not less than $\mathbf{3 0}$ dirhams and for those who can not afford, is enough just its ability. In addition, according to Ibn al-Muhairiz, the rate of mut'ah who is circumcised is 30 dinar. If you compare the value to the current currency, of course, this amount is very high. However, based on the opinion of Imam Ahmad bin Hanbal and al-Syirbibi of Shafi'i sect, the minimum rate for mut' ah is circumcised not less than 30 dirhams. While the maximum rate can not be more than the value of a servant (khadam) (Syirbini, 1958). Although there is no nasqa (aqqah) in the rate required but fuqaha' agrees that there are two principles in relation to the determination of this mut'ah rate:

i. Seen on the ability of the husband as well as based on the nasab and the nature of the divorced wife. If the husband is a wealthy and high income group, then raise the value of mut'ahnya so that it can be a slave (khadam) or equivalent. In addition, if a husband consists of a middle class that is neither rich nor poor, then his mut'ah rate is moderate enough as a piece of clothing that covers aurat or its worth. Furthermore, if the husband belongs to the poor, then his mut'ah rate is sufficient only for his ability (Syafa, 1995; Papavasileiou, 2018).

ii. Return to Judgment as it requires ijtihad. In the event of a dispute, the Judge must determine the rate based on the circumstances of both husband and wife. The determination of mut'ah rate is measured based on the ability of the husband and the nasab and the nature of the wife. The Judge's decision must be fair with regard to the circumstances of both parties.

In conclusion, when it comes to the verses found in the Quran, al-Hadith and ijtihad of the fuqaha', it is concluded that the mut'ah rate is not clearly defined and absolute by any Quranic verses or al-Hadith. Therefore, the ideal rate is the amount agreed or favored by both parties. If the agreement is not reached, the Judge has the authority to determine it on the basis of ijtihad by taking into account four such matters:

i. Husband's ability (rich or poor).

ii. Family condition (offspring) wife. 
iii. The character (character) of the wife.

iv. Judgment of the Judge (court) that the amount is "proper and proper" in accordance with Hukum Syarak.

Husband's ability (rich or poor) is the present value in terms of procurement and selection. On the other hand, character is the character and condition of family status or family status in society.

\section{The Woman Right to Mut'ah}

The wife has the right to mut'ah in the event of divorce caused by the husband such as divorce through talaq, li'an, ila 'or the husband of impotence or no genitals, apostasy or refusing to embrace Islam. This has been agreed upon by the jurists fuqaha'. Only scholars of the Maliki sect have the opinion that the mut'ah law is circumcised. While in a clear opinion of the Syafi'i sect, states that the mut'ah is compulsory to all divorced spouses either before sexual intercourse or after intercourse. In fact, according to the opinion of ulama 'salaf such as Saidina Ali bin Abu Talib, Abd Allah bin Umar, Hassan al-Basri, Sa'id ibn Jubair and Abu Qilabah states that mut'ah must be fulfilled even though the wife has been determined dowries and this opinion which is more authentic and meets the requirements of Hukum Syarak. So in this context, the husband must perform mut' ah against the divorced wife, as soon as it is resolvedby deliberation by both parties. If the rights are neglected, the husband is guilty of sin and Judge is entitled to compel him when charged to court. (Al-Hassan, 1993)

Fuqaha' different opinion in determining the law whether the wife of slave women is also entitled to mut'ah. Al-Auza'i argued that the living expenses of a servant such as maintenance and daily necessities were borne by his master. Therefore, they are not required to be mut'ah. The reason is that they do not need the mut'ah property to support life. However, there is a fuqaha' argue otherwise, that the husband is obliged to give mut'ah to the divorced wives whether his wife is an independent woman or slave. For example, in the book l'lanat al-Talibin (Ahmed, 1983):

"It is obligatory for a husband to pay mut'ah to a wife who has been touched even if it is a slave (amah) by reason of a divorce which is not his or her and a divorce which is not for the death of one of the two".

The wife who is entitled to mut'ah is the wife who is divorced by her husband without cause or by reason of not coming from himself or herself. In other words, the separation occurred due to the husband either through divorce talaq, li'an, ila 'and fasakh. The wife also deserves mut'ah even though the talaq has been handed to the wife as a ta'lik divorce. Here is the condition of the wife who is divorced and entitled to mut'ah, namely:

i. Wives divorced by husbands prior to the relationship between the two during the marriage period and whether or not they have determined their dowry or have not been determined yet. If dowry has been set, the mut'ah value is half the value of the dowry. According to the jumhur fuqaha' and based on the word of Allah S.W.T in Surah al-Baqarah, verse 237, the granting of mut'ah in this context is obligatory (Nawawi, 1970).

ii. Wives divorced by the husband after the occurrence of the relationship between husband and wife even during the duration of their marriage and whether or not their dowry has been 
determined. Fuqaha ' differ in opinion in mut'ah mut'ah based on this divorce. Part of the jurisprudence' comprising scholars of' Mazhab al-Syafi'i argues that the mut'ah law is obligatory. (al-Syirazi, 1976)

iii. Divorced wives for talaq redemption are entitled to mut'ah. The reason is divorce through talaq redemption is also considered the same as divorce through talaq (Al-Husayni, 1983)

iv. Those divorced by husbands refuse to embrace Islam or apostate husband. However, in this case it must have been that the husband did not belong to the cautious. While mut'ah is only able to be fulfilled by only those who are cautious. If the unbelieving or apostate husband gives mut'ah, then the wife deserves it. (al-Aynayn, 1995)

v. A wife who was defamed with her husband because of the incestuous act committed by her husband. For example, a husband commits sexual misconduct with one of the family members of his wife such as adultery with a brother-in-law or a wife's spouse. This act causes the relationship of husband and wife to be illegal forever. Because it is not the mistake of the wife but comes from the husband, then he is worthy and entitled to mut'ah. (Al-Husayni, 1983)

In conclusion, that is among several divorced wives and entitled to mut'ah. This condition means that mut'ah is compulsory for divorce whether before or after the roles of marriage during marriage and as far as separation is not caused by the wife or his party. In addition, divorce through talaq also does not affect their rights to mut'ah disadvantages of certain groups as stated above.

\section{Conclusion}

The description and discussion shows that mut'ah is one of the rights that the husband has to give to his divorced wife. In addition, it is also an award given by Allah S.W.T to his servant and is also a symbol of Islamic concern for the fate of women.

Furthermore, husbands can not indiscriminately release the responsibilities entrusted to his wives as determined by Allah S.W.T whether during marriage or after the occurrence of divorce. Islam does not encourage divorce and live a single life and decides libido because it is against the norms of society and the nature of human events. However, Islam does not close the divorcee's door. Hence it is the last resort if the goal of the marriage fails and is more harmful if the bond continues.

According to Islam, divorce does not mean that husbands can discharge their responsibilities to arbitrary wives. Therefore, in order to ensure that justice is upheld and achieved and does not persecute the ex-wife, Islam has allocated some of the rights of the wife to be fulfilled by the husband after divorcing his wife. Among those rights are the dowry if not settled during the contract or during marriage, iddah maintenance, property of sepencarian, land and mut'ah.

In this case, Allah S.W.T has stressed the obligation to pay mut'ah to divorced wife. According to His words:

يا أيها النبي قل لأزواجك إن كنتن تردن الحياة الدنيا وزينتها فتعالين أمتعكن وأسرحكن سراحا جميلا * وإن كنتن تردن الله

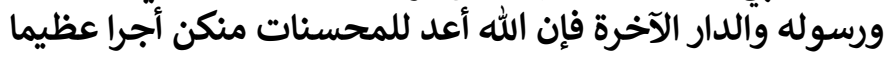
It means: "O Prophet, say to your wives: "If you desire the life of the world and its ornaments, then come to me to give you mut'ah (consolation) and I divorce you in a good way. And if you 
INTERNATIONAL JOURNAL OF ACADEMIC RESEARCH IN BUSINESS AND SOCIAL SCIENCES

Vol. 9, No. 11, November, 2019, E-ISSN: 2222-6990 @ 2019 HRMARS

desire the pleasure of Allah and His messenger and the provision of the Hereafter, verily Allah has prepared for those who do good among you a great reward."

(Surah al-Ahzab (33): 28-29)

\section{Acknowledgement}

This paper is founded on the research project of the Fundamental Research Grant Scheme FRGS/1/2018/SSI03/UNISZA/02/2 (Project No: RR279). Special appreciation is owed to Ministry of Higher Education Malaysia (MOHE) and Universiti Sultan Zainal Abidin (UniSZA) for sponsoring and supporting this research.

\section{Corresponding Author}

Wan Khairul Aiman bin Wan Mokhtar (Ph.D), Senior Lecturer, Universiti Sultan Zainal Abidin (UniSZA), Kampus Gong Badak, 21300 Kuala Nerus.

E-mail:wk_aiman@yahoo.com / wkhairulaiman@unisza.edu.my

\section{References}

Anal, A., Ahmad, A. C., Razalli, A. R., \& Min, L. H. (2018). Career Transition Practice from Student Development Aspect: Best Practices in the Implementation of Special Skills Certificate Program in Malaysian Community College. International Journal of Academic Research in Progressive Education and Development, 7(4), 122-133.

Al-Bustani. (1960). Kitab al-Muhit. Beirut: Maktabah Lubnan.

Al-Fariti, A. (2004). "Setti Lea Nati Khong Faria Tarm Kodmai Islam" (Hak dan

Al-Hulliyy, H. (1993). Figh Lima Mazhab di Antara Nas dan Itihad. (Dr Lutpi Ibrahim, Trans.) Jil. 2. Selangor: Al-Wahdah Publication.

Al-Husayni. (1983). Kitab Kifayat al-Akhyar. Jil. 3. Beirut: Dar al-Fikr.

Al-Malibari, Z. D. (1983), Syarih: Abi Bakr al-Sayyid Shata al-Bakri al-Dimyati, Dar al-Nawadir. Syria,

Anis, I. (1972). Mu'jam Al-Wasit. Juz 2. Kaherah: Syarikat al-I'lanat al- Syariqiyyah. Babi al-Halabi wa Awladih.

Che'arong, A. R. (2004). "Seeti Khong Fariya Naikarn Yā Lea Setti Ti Feng Dairab Tarm Kodmai Islam" (Hak Isteri dalam Bercerai dan Jaminannya

Firuzabadi al-Syirazi. (1976). al-Muhadhdhab. Juz 2. Mesir: Matba'at 'Isa al-Babi al-Halabi.

Golpaygani, S. M. (1992). Resalah (Epistle). Cet. 2. Qom: Dar al-Quran al-Karim.

Ibn al-Manzur. (1990). Lisan al-Arab. Jil. 8. Beirut: Dar Ihya' al-Turath al-Arabi.

Ibn al-Murtada. (1975). Kitab al-Bahr al-Zakhkhar. Beirut: Muassasat al-Risalah.

Ibn-Juzayy. (1968). Qawanin al-Ahkam al-Syari'yah. Beirut: Dar al-'Ilm al-Malayin.

Ibn-Murtada. (1975). Kitab al-Bahr al-Zakhkhar. Beirut: Muassasat al-Risalah.

Ibn-Qudamah. (1981). al-Mughni. Juz 8. Riyadh: Maktabat al-Riyadh al-Hadithah.

Ibn-Rusyd. (1970). Bidayat al-Mujtahid. Kaherah: Maktabat wa Matba'at Mustafa al-

Ibrahim, A. (1999). "Undang-Undang Keluarga Islam di Malaysia”, Malayan

Keluarga Islam: Konsep dan Perlaksanaannya di Malaysia. Kuala Lumpur: Karya Abazie. 
INTERNATIONAL JOURNAL OF ACADEMIC RESEARCH IN BUSINESS AND SOCIAL SCIENCES

Vol. 9, No. 11, November, 2019, E-ISSN: 2222-6990 ㄷ 2019 HRMARS

Law Journal.

Majid, M. Z. A. \& Azahari, R. (1980). Undang-Undang

Maman, S. A. (2006). Introduction to Legal System Comparisons. Cet. 2. Jakarta: Rajawali Pers. Mengikut Undang-Undang Islam). Pattani: Disertasi Jabatan Kemanusiaan, Universiti

Mokhtar, W. K. A. W. (2017). Concept Al-Hadīth Al-Mawḍu'iy as a Method of Collecting and Analyzing Research's Data. International Journal of Academic Research in Business and Social Sciences, 7(2), 2222-6990.

NjimuM, Theuri, M. M., Kiragu, D. (2018). Organizational Micro Level Determinants of Survival of Youth Owned Micro and Small Enterprises in Nyeri County, Kenya, International Journal of Academic Research in Accounting, Finance and Management Sciences 8 (4): 81-89.

Papavasileiou, C. H. (2018). Reading Strategies of Homophone Lexemes in Toddlers . Multilingual Academic Journal of Education and Social Sciences, 6(1), 94-112 (in Greek).

Razi. (1974). Tafsir al-Fakhr al-Razi. Beirut: Dar al-Fikr.

Songkla Nakarin Pattani.

Syatibi. (1991). al-Muwafaqat fi Usul al-Syariah. Juz 4. Beirut: Dar al-Kutub al-IImiyah Tugas Isteri Mengikut Undang-Undang Islam). Songkhla: Disertasi Jabatan Kemanusiaan Universiti Songkhla Nakarin.

Yaacob, A. M. (1999). Undang-undang Keluarga Islam dan Wanita di Negara-Negara ASEAN. Kuala Lumpur: Institut Kefahaman Islam Malaysia (IKIM). 